\title{
The Suitability of Body Scanning Measurement in Pattern Drafting Methods
}

\author{
Maryam AHMED *, Tarfah ALRUSHAYDAN, Simeon GILL, Steven G. HAYES, Kristina BRUBACHER \\ The University of Manchester, Manchester, UK
}

\author{
https://doi.org/10.15221/19.058
}

\begin{abstract}
There has been much recognition that body scanning can provide more data on the human body than traditional measurements alone. Nevertheless, it is not always possible to extract the many measurements that are required by existing methods of pattern construction, due to the differences in the measurements captured between manual and body scanning methods. The conventional methods that are used for drafting pattern blocks do not incorporate data pertaining to body measurements to a large extent. This can be traced back to the fact that traditional pattern drafting approaches are from a time when obtaining some measurements were difficult and certain measurements were easier to extract than others. To overcome the lack of data, post-drafting modifications are performed to accomplish an appropriate fit, and most pattern books are accompanied with detailed guidance as to how to adjust the blocks to take into consideration typical figure disparities. Body scanning technology makes it possible to acquire body configuration data that has been traditionally challenging to access. This type of technology can be employed to investigate body shapes and collate pertinent measurements. It can also be employed to delineate dimensions, something that was not previously possible. Moreover, appropriate scan data allows a challenge to existing drafting methods and the proposal of new ways of creating patterns that is based on actual measurements rather than proportional relationships. This study commences by analysing existing $2 \mathrm{D}$ pattern construction methods and the myriad outputs of body scanning technology to examine the extent to which body scanning can complement conventional pattern drafting approaches. Ten pattern-making techniques for bodices and trousers were assessed, and the measurements that were needed for these techniques were compared to the measurements that were generated by a body scanning system. The research established how well the measurements required for different drafting methods can be produced from 3D body scanning technology. The main contribution of this study is to highlight where measurements that are required for pattern construction be defined as outputs within body scanner systems. This would allow the body scanner to offer more suitable measurement support for pattern drafting methods.
\end{abstract}

Keywords: Accuracy, Reliability, Made-to-Measure, 3D Body Scanning, Anthropometrics, Pattern Construction.

\section{Introduction}

Most research has reported that using a specific pattern drafting method for different body shapes or sizes yields varied results [1]-[5]. This highlights the need for differently shaped garments to achieve good fit and the importance of developing a method of taking measurements and pattern construction methods to better reflect individuals or populations variability. Developing methods of taking measurements suitable to inform pattern drafting would offer a solid foundation and help us to better understand the relationship between the body and the pattern. This relationship was embedded in early tailoring texts [6], [7] though they had limited measurement tools, but is rarely explicitly covered in modern pattern making methods, which have greatly enhanced measurement technologies.

Body scanning allows us to capture data of the body that has historically been difficult to capture[8]. With it, we can explore shape and also collect new measurements, as well as define dimensions, which were not possible previously with the equipment available. Using 3D body scanning allows the challenging of existing techniques, as well as the proposal of new ways of creating patterns, better informed by the body. This paper examines the appropriateness of measurements derived from a three-body scanner with those required to create clothing patterns according to several different methods of drafting patterns to bodice and trousers for women.

Offering more suitable measurement support pattern drafting methods from body scanning would benefit significantly apparel design educators and practitioners. it helps them to better understand the body-to-pattern relationships. The time and costs of the numerous fittings needed to perfect a pattern for a garment could be reduced or even eliminated by the implementation of more accurate approaches to pattern-making, using 3D body scanning technology and its enhanced analysis.

*maryam.ahmed-5@postgrad.manchester.ac.uk 


\subsection{Aims and Objectives}

This study starts by analysing existing 2D pattern construction methods and determines the measurements required by these methods. Measurements are then compared to those produced by the Size Stream body scanning software and those possible to extract using the custom measurement creator and in built manual scan measurement tools. This allows the examination of the extent to which body scanning can complement conventional pattern drafting approaches.

- This paper determinates the suitability of body scanning measurement in existing pattern drafting methods.

- This study also suggests some further measurements that can be produced by body scanners, which are required to draft well-fitted garments that response better to individual bodies. This overcomes the limitations of pattern drafting where proportional systems of measurement determination were used for measurements which were difficulty to capture with conventional manual tools.

\section{Methodology}

\subsection{Selection of pattern drafting methods}

Ten methods for drafting women's bodices and trousers were selected for this analysis [9]-[18](see Table 1). Each method provides necessary instructions to draft bodice and/or trousers block and includes guidance for collecting the required measurements.

Table 1. Pattern drafting methods selected

\begin{tabular}{|l|l|l|}
\hline Draft Method & Bodice & Trousers \\
\hline (Aldrich, 2015) & $\begin{array}{l}\text { page (214-215) } \\
\text { page (62-63) }\end{array}$ & $\begin{array}{l}\text { Page (166-167) } \\
\text { Page (214-215) }\end{array}$ \\
\hline (Armstrong, 2014) & $\begin{array}{l}\text { page (34-39) } \\
\text { page (46-49) }\end{array}$ & $\begin{array}{l}\text { Page (667-671) } \\
\text { Page (661-663) }\end{array}$ \\
\hline (Beazley and Bond, 2003) & $\begin{array}{l}\text { page (2-5) } \\
\text { page (33-37) }\end{array}$ & $\begin{array}{l}\text { Page (41-45) } \\
\text { Page (40) }\end{array}$ \\
\hline (Bunka, 2009) & - & $\begin{array}{l}\text { Page (138-143 } \\
\text { Page (136-137) }\end{array}$ \\
\hline (ESMOD, 2009) & $\begin{array}{l}\text { page (30-31) } \\
\text { page (62-67) }\end{array}$ & $\begin{array}{l}\text { Page (36-237) } \\
\text { Page (14) }\end{array}$ \\
\hline (Holman, 1997) & page (38-41) & page (110-111) \\
\hline (Khalil, 1985) & page (145-160) & Page (385-392) \\
\hline (Kunick, 1967) & - & Page (134-136) \\
\hline (Shoben \& Ward 2000) & - & Page (714) \\
\hline (Thatha, 1995) & page (18-30) & $\begin{array}{l}\text { Page (396-402) } \\
\text { Page (393-394) }\end{array}$ \\
\hline
\end{tabular}

\subsection{Analysis and comparison of measurements for chosen methods and body scanners}

A critical analysis and comparison were undertaken to determine the different measurements required for each pattern drafting method. This was done by determining the measurements specified for the draft, analysing the method and identifying any further measurements required during the process of drafting.

An Excel spreadsheet was created using guidance for placement and measurement taking, as defined by each pattern construction method. Similar measurements were grouped together under a collective heading whenever possible and when measurements were defined differently, they were separated.

These measurements were then compared to those available from the list of core measurements in Size Stream Studio version 5.2.9. An example of this analysis can be seen in Table $2 \& 3$ and is based on methods used to create bodice blocks. Similar approaches were taken for other drafting methods of different patterns. 
Discussion within the research group showed common approaches toward pattern drafting and allowed for a range of comparisons to be made. It was also possible, using this analysis, to determine where body scanning could offer data that might allow pattern drafting methods to better reflect an individual's size, shape and proportions.

Table 2: Measurements required for bodice pattern blocks and those provided by Size Stream body scanner

\begin{tabular}{|c|c|c|c|c|c|c|c|c|}
\hline Ald 2004 & Arm 2010 & B\&B 2003 & Esm 2009 & Hol 1997 & Kha 1985 & Tha 1995 & Measurement Name & $\begin{array}{l}\text { Size Stream } \\
\text { Measurement }\end{array}$ \\
\hline \multirow{2}{*}{ Bust } & Bust arc & \multirow{2}{*}{ Bust girth } & \multirow{2}{*}{ Bustline } & \multirow{2}{*}{ Bust } & \multirow{2}{*}{ Bust girth } & \multirow{2}{*}{ Bust girth } & \multirow{2}{*}{ Bust } & $\begin{array}{c}\text { Chest / Bust } \\
\text { Circumference (\& Fr } \\
\text { Arc) }\end{array}$ \\
\hline & Back arc & & & & & & & $\begin{array}{c}\text { Chest / Bust } \\
\text { Circumference Bk Arc }\end{array}$ \\
\hline \multirow{2}{*}{ Waist } & Front waist arc & \multirow{2}{*}{ Waist } & \multirow{2}{*}{ Waistline } & \multirow{2}{*}{ Waist } & \multirow{2}{*}{ Waist } & \multirow{2}{*}{ Waist } & \multirow{2}{*}{ Waist } & $\begin{array}{c}\text { OPT Waist Circ \& Fr } \\
\text { Arc }\end{array}$ \\
\hline & Back waist arc & & & & & & & OPT Waist Circ Bk Arc \\
\hline \multirow[t]{2}{*}{ Back width } & & & Cross-back & Cross Back & & & \multirow{2}{*}{ Across Back } & \\
\hline & Across back & Across back & & & Half back width & & & $\begin{array}{c}\text { Across Back Tape } \\
\text { Measurement }\end{array}$ \\
\hline \multicolumn{9}{|l|}{ Chest } \\
\hline & \multirow[t]{2}{*}{ Across chest } & & \multirow[t]{2}{*}{ Cross-front } & \multirow[t]{2}{*}{ Cross Chest } & & & \multirow[t]{2}{*}{ Across Front } & \\
\hline & & Across front & & & & & & $\begin{array}{c}\text { Across Chest Arm to } \\
\text { Arm Length }\end{array}$ \\
\hline Shoulder & Shoulder length & Shoulder length & Shoulder length & Shoulder length & Shoulder length & Shoulder length & Shoulder Length & Shoulder Length Right \\
\hline \multirow[t]{3}{*}{ Neck size } & & Neck girth & Neckline & Neck & $\begin{array}{c}\text { Neck } \\
\text { circumference }\end{array}$ & & \multirow{2}{*}{$\begin{array}{l}\text { Neck Base } \\
\text { Measurement }\end{array}$} & Neck Circumference \\
\hline & Back neck & & & & & & & \\
\hline & CF length & & Centre front line & $\begin{array}{l}\text { Centre Front } \\
\text { Bodice }\end{array}$ & & & $\begin{array}{c}\text { Centre Front Neck to } \\
\text { Waist }\end{array}$ & \\
\hline \multirow[t]{14}{*}{ Nape to Waist } & CB Length & Nape to waist & Centre back line & $\begin{array}{c}\text { Centre Back } \\
\text { Bodice }\end{array}$ & Back length & Back length & $\begin{array}{c}\text { Centre Back Neck to } \\
\text { Waist }\end{array}$ & $\begin{array}{c}\text { Half Back Center Tape } \\
\text { Measure }\end{array}$ \\
\hline & Bust span & $\begin{array}{c}\text { Bust prominence } \\
\text { width }\end{array}$ & Half bust value & & $\begin{array}{c}\text { Bust prominence } \\
\text { width }\end{array}$ & & Bust Width & $\begin{array}{l}\text { Bust-to-Bust Length } \\
\text { (Custom) }\end{array}$ \\
\hline & & & Bust length & & & & $\begin{array}{c}\text { Centre front neck to } \\
\text { Bust point }\end{array}$ & \\
\hline & \begin{tabular}{|c|}
$\begin{array}{c}\text { Across shoulder } \\
\text { (front) }\end{array}$ \\
\end{tabular} & & & & & & $\begin{array}{c}\text { Centre Front Neck to } \\
\text { Shoulder }\end{array}$ & Front Shoulder Width \\
\hline & \begin{tabular}{|c|}
$\begin{array}{c}\text { Across shoulder } \\
\text { (back) }\end{array}$ \\
\end{tabular} & & & & $\begin{array}{l}\text { Shoulder width } \\
\text { from nape }\end{array}$ & & $\begin{array}{c}\text { Centre Back Neck to } \\
\text { shoulder }\end{array}$ & Back Shoulder Width \\
\hline & \begin{tabular}{|c|}
$\begin{array}{c}\text { Dart placement } \\
\text { front }\end{array}$ \\
\end{tabular} & & & & & & $\begin{array}{c}\text { Waist Dart placement } \\
\text { (front) }\end{array}$ & \\
\hline & $\begin{array}{c}\text { Dart placement } \\
\text { back }\end{array}$ & & & & & & $\begin{array}{c}\text { Waist Dart placement } \\
\text { (back) }\end{array}$ & \\
\hline & & $\begin{array}{l}\text { Front length to } \\
\text { bust }\end{array}$ & & & & & $\begin{array}{c}\text { Centre Back Neck to } \\
\text { BP }\end{array}$ & $\begin{array}{l}\text { Cervicale to Bust } \\
\text { Length }\end{array}$ \\
\hline & & Front waist level & & & & & $\begin{array}{c}\text { Centre Back Neck to } \\
\text { Waist (pass BP) }\end{array}$ & \\
\hline & & $\begin{array}{c}\text { Front neck point } \\
\text { to bust point }\end{array}$ & & & Bust point length & & Side Neck Point to BP & $\begin{array}{c}\text { Side Neck to Bust } \\
\text { Length Right }\end{array}$ \\
\hline & & $\begin{array}{c}\text { Front neck point } \\
\text { to waist }\end{array}$ & & & Bust length & Bust length & $\begin{array}{l}\text { Side Neck Point to } \\
\text { waist (pass BP) }\end{array}$ & \\
\hline & Full length (front) & & & \begin{tabular}{|c|}
$\begin{array}{c}\text { Shoulder to } \\
\text { Waist }\end{array}$ \\
\end{tabular} & & & $\begin{array}{c}\text { Side Neck Point to } \\
\text { Front Waist }\end{array}$ & \\
\hline & Full length (back) & & & $\begin{array}{c}\text { Back shoulder to } \\
\text { waist }\end{array}$ & Back length & & $\begin{array}{c}\text { Side Neck Point to } \\
\text { Back Waist }\end{array}$ & \\
\hline & Strap & & & & & & $\begin{array}{l}\text { Side Neck Point to } \\
\text { Side Seam }\end{array}$ & \\
\hline $\begin{array}{c}\text { Front shoulder to } \\
\text { waist }\end{array}$ & & & & & & & $\begin{array}{c}\text { Middle Shoulder to } \\
\text { Waist }\end{array}$ & \\
\hline \multirow[t]{9}{*}{ Armscye Depth } & & Armhole Depth & & Armhole Depth & & & Armhole Depth & $\begin{array}{c}\text { Back Neck to Back } \\
\text { Chest }\end{array}$ \\
\hline & $\begin{array}{c}\text { shoulder slope } \\
\text { (front) }\end{array}$ & & & & & & $\begin{array}{c}\text { Shoulder Tip to CF } \\
\text { Waist }\end{array}$ & \\
\hline & $\begin{array}{c}\text { shoulder slope } \\
\text { (back) }\end{array}$ & & & & & & $\begin{array}{c}\text { Shoulder Tip to CB } \\
\text { Waist }\end{array}$ & \\
\hline & Bust depth & & & & & & Shoulder Tip to BP & \\
\hline & side length & & & & & & Side Seam Length & \\
\hline & & $\begin{array}{l}\text { Width of } \\
\text { Armhole }\end{array}$ & & & & & Width of Armhole & \\
\hline & & Measurement is in & ncorporated into & nother measureme & hent or a simlar $n$ & asurement is taken & & \\
\hline & & Measurement not & required within th & guidance & & & & \\
\hline & & Measurement no & urrently avaiab & from scanner & & & & \\
\hline
\end{tabular}


Table 3: Measurements required for trousers pattern blocks and those provided by Size Stream body scanner

\begin{tabular}{|c|c|c|c|c|c|c|c|c|c|c|c|c|}
\hline Ald 2015 & Arm 2010 & B\&B 2003 & Bun 2009 & Esm 2009 & Hol 1997 & Khal 1985 & Kun 1967 & $\begin{array}{l}\text { Shoben \& Ward } \\
1987\end{array}$ & $\begin{array}{l}\text { Shob and War } \\
2000\end{array}$ & Tha 1995 & Measurement Name & $\begin{array}{c}\text { Size Stream } \\
\text { Measurement }\end{array}$ \\
\hline \multirow{2}{*}{ Waist } & Front Waist arc & \multirow{2}{*}{ Waist Girth } & \multirow{2}{*}{ Waist } & \multirow{2}{*}{ Waist Measurement } & \multirow{2}{*}{ Waist } & \multirow{2}{*}{ Waist } & \multirow{2}{*}{ Waist Girth } & \multirow{2}{*}{ Waist } & \multirow{2}{*}{ Waist } & \multirow{2}{*}{ Waist } & \multirow{2}{*}{ Waist Circumference } & $\begin{array}{l}\text { OPT Waist Circ \& Fr } \\
\text { Arc }\end{array}$ \\
\hline & Back Waist arc & & & & & & & & & & & OPT Waist Circ Bk Arc \\
\hline & & Upper Hips Girth & Mid Hips & Small Hips & & Upper Hips & & Top Hips & & & $\begin{array}{l}\text { Upper Hips } \\
\text { Circumference }\end{array}$ & High Hips \\
\hline & & & & & & & High Hip Girth & (2) & & & & the fortom \\
\hline \multirow[t]{7}{*}{ Hips } & Front Hip arc & \multirow[t]{2}{*}{ Hips Girth } & & \multirow[t]{2}{*}{$\begin{array}{l}\text { Full Hips } \\
\text { Measurement }\end{array}$} & Hips Cir & Hips Cir & \multirow[t]{2}{*}{ Hips Girth } & \multirow[t]{2}{*}{ Hips Cir } & & \multirow[t]{2}{*}{ HipsCir } & \multirow{3}{*}{ Hips Circumference } & $\begin{array}{l}\text { Hip Circumference \& Fi } \\
\text { Arc }\end{array}$ \\
\hline & Back Hip arc & & Hips Measurement & & & & & & & & & \\
\hline & & & Around the Thich & & & & & & & & & Arc \\
\hline & Upper Thigh & Thigh Girth & Around the Thigh & & & Thigh Cir & & Thigh Cir & Seat Direct & Thigh Cir & $\begin{array}{l}\text { Thigh Circumference } \\
\text { Seat Circumference }\end{array}$ & $\begin{array}{l}\text { Thigh Circumference } \\
\text { Seat Circumference }\end{array}$ \\
\hline & & & & & & & $\begin{array}{c}\text { Abdomen-Seat } \\
\text { Diameter }\end{array}$ & & & & Abdomen Seat & $\begin{array}{c}\text { Abdomen } \\
\text { Circumference }\end{array}$ \\
\hline & Knee arc & Knee Girth & Around the Knee & Knee Measurement & & & Knee Circumference & $\begin{array}{c}\text { Knee } \\
\text { Circumference }\end{array}$ & & & Knee Circumference & Knee Circumference \\
\hline & Calf arc & Calf Girth & & & & & Calf Circumference & Calf Circumference & & & Calf Circumference & Calf Circumference \\
\hline $\begin{array}{c}\text { High Ankle } \\
\text { Circumference }\end{array}$ & & & \begin{tabular}{|l} 
Around The Lower \\
Leg
\end{tabular} & & & & & & & & $\begin{array}{c}\text { High Ankle } \\
\text { Circumference }\end{array}$ & \\
\hline $\begin{array}{c}\text { Ankle } \\
\text { Circumference }\end{array}$ & Ankle arc & Ankle Girth & Around the Ankle & & & & Ankle Circumference & \begin{tabular}{|c} 
Ankle \\
Circumference \\
\end{tabular} & & & Ankle Circumference & Ankle Circumference \\
\hline \multirow[t]{2}{*}{ Waist to Hips } & \multirow[b]{2}{*}{ Crutch Depth sea } & Hips Level & & $\begin{array}{c}\text { Waist to Hips } \\
\text { Length }\end{array}$ & Waist to Hips & & Waist to Hips & & & & \multirow[t]{2}{*}{ Waist to Hips } & \\
\hline & & & Hips Depth & & Crutch Depth & $\begin{array}{l}\text { Waist to Hip } \\
\text { Boydrise }\end{array}$ & Body Rise & Body Rise & & $\begin{array}{l}\frac{\text { Waist to Hips }}{\text { Body Rise }} \\
\end{array}$ & & \multirow{3}{*}{ Front Vertical Rise } \\
\hline \multirow{3}{*}{ Body Rise sea } & & & \begin{tabular}{|c|} 
Subtracting for \\
inside leg length \\
from th pants
\end{tabular} & & & & & Body Rise & & & \multirow[t]{2}{*}{ Crutch Depth } & \\
\hline & & & & Riser Measurement & & & & & Body Rise Direct & & & \\
\hline & Crutch Length & & Crutch Length & $\begin{array}{c}\text { Crutch } \\
\text { Measurement }\end{array}$ & & & & & & & Crutch Length & $\begin{array}{l}\text { Crutch Length Full } \\
\text { Front Crutch Lenght } \\
\text { Back Crutch Length }\end{array}$ \\
\hline \multirow[t]{2}{*}{ Waist to Knee } & & \multirow{2}{*}{ Waist to Knee } & & & Waist to Knee & & & Waist to Knee & & & \multirow{2}{*}{ Wais to Knee } & \\
\hline & & & & Waist to Knee & & & Waist to Knee & & & & & \\
\hline \multirow{2}{*}{ Waist to floor $C B$} & Waist to Ankle & Outside Leg Length & $\begin{array}{l}\text { Pants Length } \\
\end{array}$ & Waist to Floor & $\begin{array}{l}\text { Outside Leg } \\
\end{array}$ & & Side Seam & \begin{tabular}{|l} 
Outside Leg Length \\
\end{tabular} & Outside Leg & Outside Leg & Outside Leg to Ankle & Outside Leg to Ankle \\
\hline & & $\begin{array}{l}\text { Inside Leg Length } \\
\end{array}$ & Inside Leg Length & & & Inside Leg Length & & & & Inside Leg & Inside leg to ankle & Inside Leg Length \\
\hline
\end{tabular}

\section{Results and Discussion}

\subsection{Measurements are not available in scanners but are required for drafting patterns}

Although there have been recent advances in terms of data used to capture measurements using body scanning, it is not always possible to extract the required measurements using existing methods of pattern construction. This is due to differences in the measurements captured between manual and body scanning methods.

The analysis of the landmarks and measurement taking method results for both pattern drafting and body scanners have shown that they are not consistent. They differ in the detail provided for measurements which is shown in Table $2 \& 3$.

In limited cases, there were no measurements available. Some measurements could be extracted using the custom measurement creator or in-built manual scan measurement tools. However, some were not available and were difficult to obtain from scanners due to their limitations in the interface. Examples of these limitations include centre front neck to waist and side seam length measurements, where enhancements to the interface would be of benefit. A more detailed description of these examples has been included in the text below.

\section{Front shoulder slope:}

This measurement is taken at the front from the landmark at centre front waist, diagonally up over the bust to each shoulder tip point. It is used within some draft methods to set the shoulder slope as well as the position of the shoulder tips [10]. Details are shown in Figure 1 below. If this measurement is not provided, a modification of the draft is required to locate this point. Currently, some scan systems cannot extract this measurement automatically. However, manual tools in body scanning provide a means to take this measurement. This measurement can be obtained using the Size Stream software by taking a multi-point line and following the contoured body surface (see Figure 2). The image shows the placement of the measurement from shoulder to CF waist, whilst this can be freely placed, it is better practice to use the automated positions of other measurements (waist, shoulder, bust) to guide its placement using manual tools. Manual extraction within the software, therefore, requires careful definition and the use of suitable guidance from other measurements to ensure consistency of placement. 


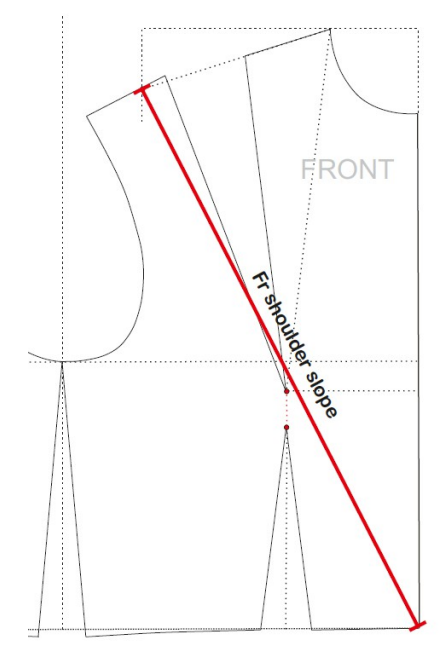

Figure 1: Measurement application in the pattern
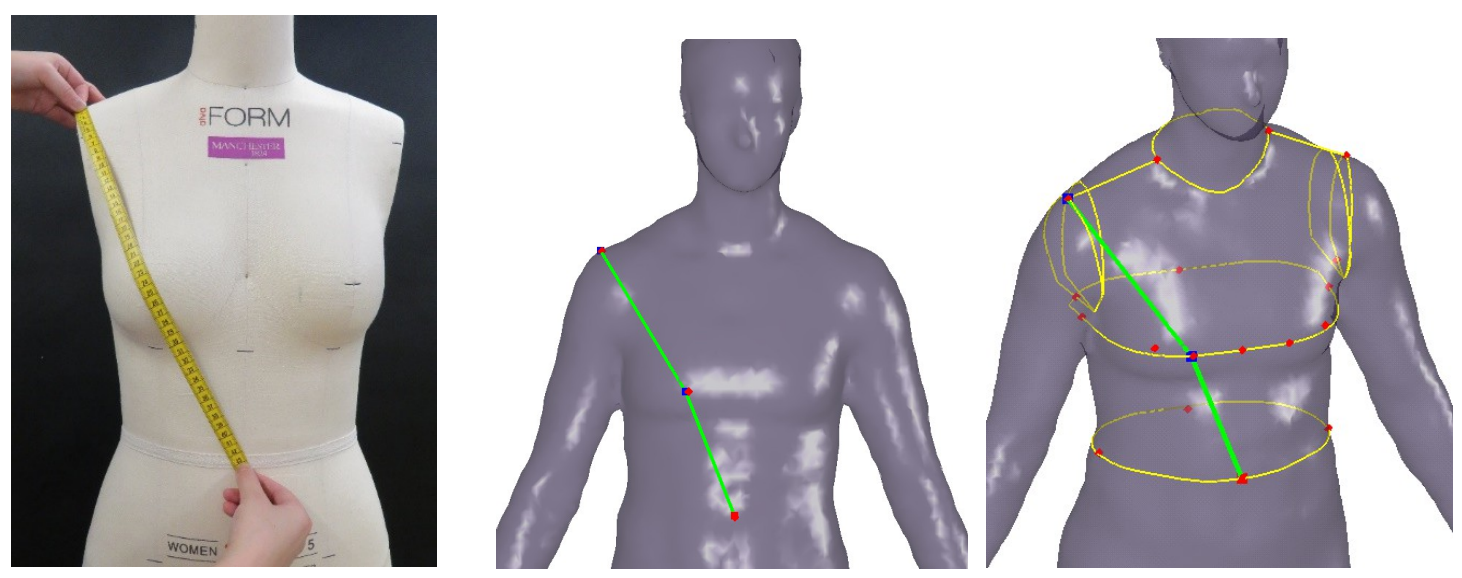

Figure 2: Shoulder tip to centre front waist measurement images

\section{Armhole width:}

The callipers are held horizontally above the subject's right arm. The calliper arms are then placed in the muscle crease of the front and back of the top of the subject's arm [19], [20]. See Figure 3 below for details. This measurement is used to locate the armhole width in the pattern [11] (see Figure 4). It can be obtained using manual tools (Line Distance between Two Points) in body scanning as demonstrated in Figure 5.
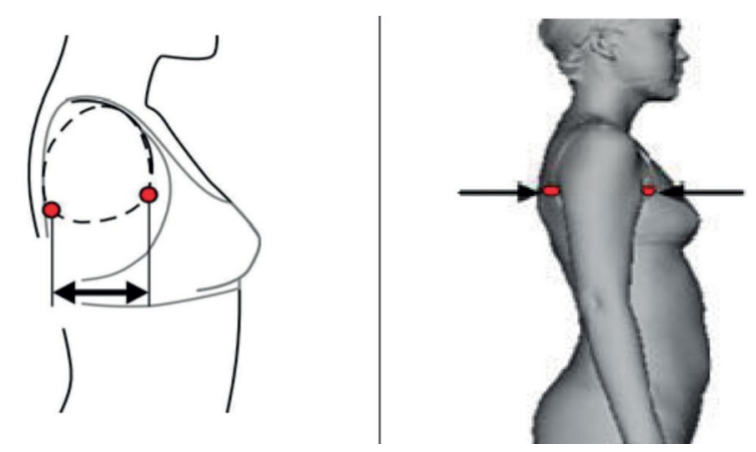

Figure 3: Horizontal distance between back and front armscye fold points Source:[21, p. 31] 


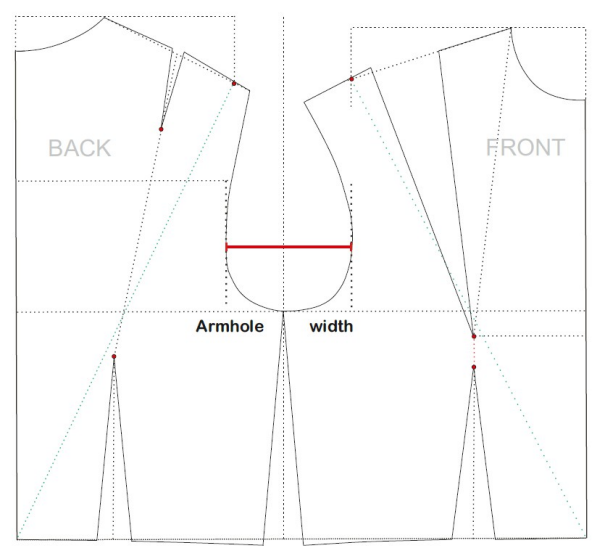

Figure 4: Measurement application in the pattern
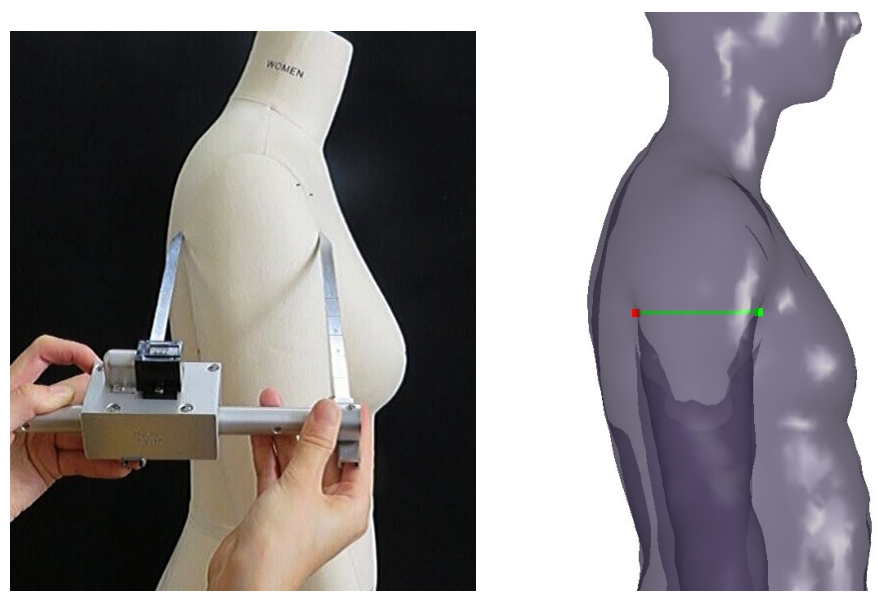

Figure 5: Armhole width measurement images

\section{Centre front neck to waist:}

Before measuring, paper, or adhesive tape, should be placed over the bust prominence to keep the tape measure in line with the anterior protrusion of the bust. Then, the measurement is taken from the centre front neck landmark over the bust prominence to the waist landmark [10]This measurement is a key measurement as it determines the position of the waist relative to the or centre front neck in the control region of upper body garments (see figure 6). Figure 7 shows that the measurement could not be taken in the scanner as the measurement should be in line with the anterior protrusion of the bust and follow the contoured body surface. It should be a curved line rather than a straight line. If points could be placed in space rather than on the body in scan software, the distance could be measured.

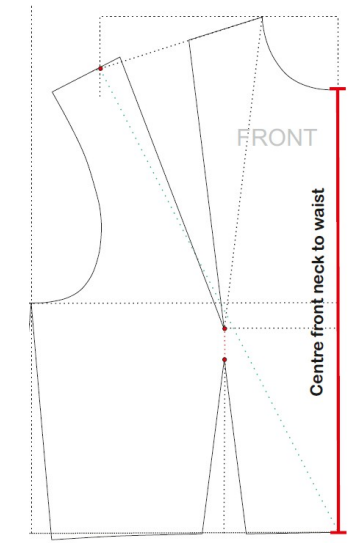

Figure 6: Measurement application in the pattern 

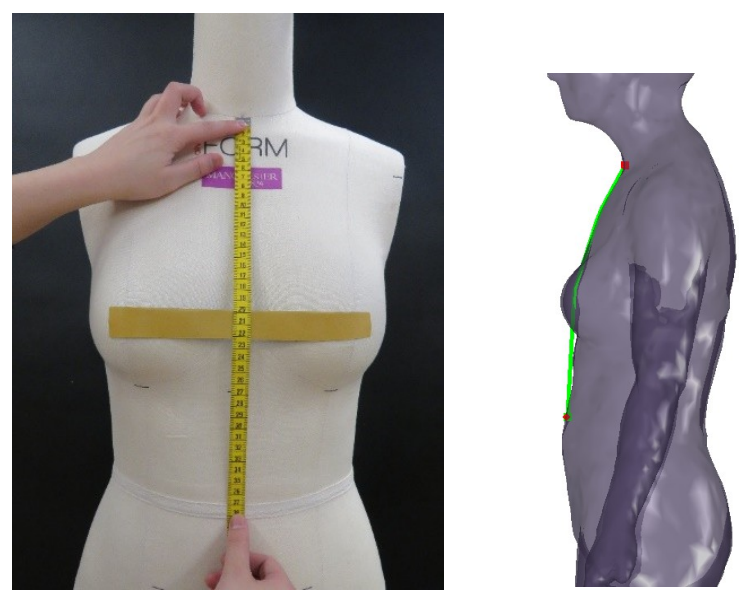

Figure 7: Centre front neck to waist measurement images

\subsection{Measurements available in scanners but not used in drafting}

Analysis of the measurement and pattern construction processes clearly show that a large proportion of the measurements used to calculate block dimensions are calculated using a proportion of the primary dimensions and this is consistent with some previous studies[22], [23].

As there are no clear correlations between the measurements and construction processes, there were difficulties employing existing size charts correctly as a guide to pattern construction. It also became clear during pattern construction that there are very few isolated measurements employed in the draft. Most measurements are applied relative to others. This makes it crucial for there to be linkage between every measurement; knowing the required distance to a minimum of one other measurement makes it more feasible to create pattern construction methodologies that are purely direct[24].

However, it is possible to extract some required measurements using existing methods of pattern construction and body scanners.

\section{Armhole curves:}

There is no guidance, or little guidance on how to draft the curves (such as armhole curves), which has led to them being drawn subjectively. Armhole circle measurement is available in scanner software and can help determine the length of the curve (see figure 8 and 9).

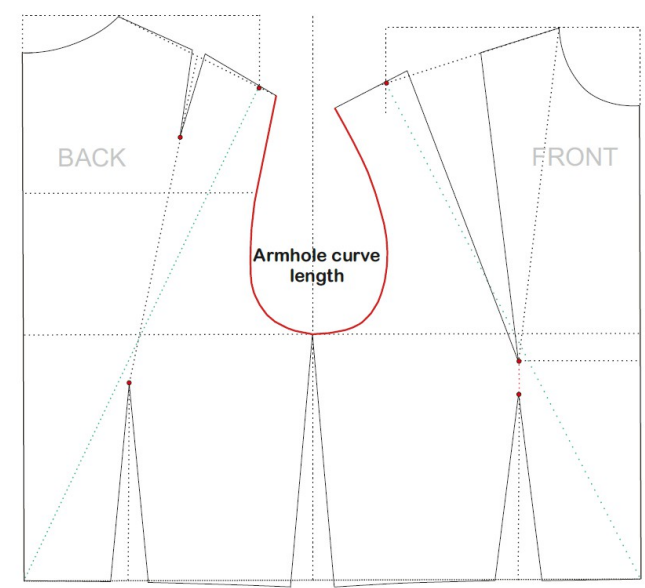

Figure 8: Measurement application in the pattern

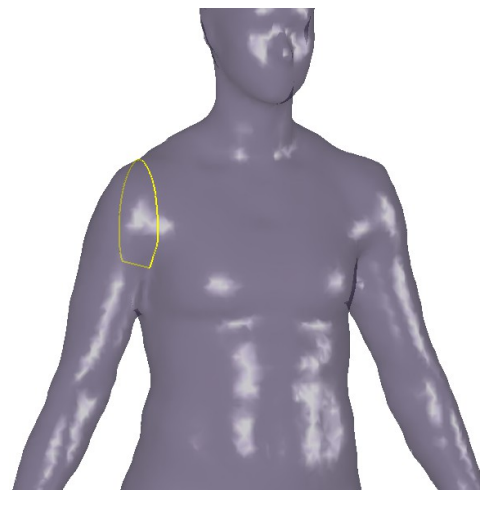

Figure 9: Armhole circle measurement image 


\subsection{Measurement are not used in drafting and not available in scanners but are worth being created}

Some measurements are not used in drafting and not available in scanners, but it would be worth creating them so does importance solve them.

Experimental studies have sought to develop and alter patterns[25], [26]. These studies incorporated conventional body measurements, graphing techniques and body angle measurements. Although the studies are dated, there are not many current studies that use previous research methods to understand body shape and angles and their relationship to pattern. Three body scanners have made it much easier to capture these dimensions and angles, rather than taking photographs as was done in previous studies.

The measurements in Figure 10 below clearly define the greatest prominence in relation to angles of the body. It can be concluded that measurement $A$ is vital to progress the methods because measurement $A$ allows us to understand how to distribute suppression for the bust around the bust region. Therefore, using the greatest prominence, it becomes possible to calculate the level of depression under the bust and how much suppression both busts equate to. The depth of suppression is already known as it is a very important measurement for understanding bust shaping.

Measurement B illustrates the shaping caused at the back by the projections of the scapula and the shoulder blade. It allows us to map the curvature running from the shoulder blade over the shoulder. Measurement $B$ is crucial to calculating the darting requirements in the back shoulder in addition to the shaping requirements.

Similarly, with back measurement $\mathrm{C}$, there is no guidance for shaping darts at the back. Instead, this is calculated using the difference between the back measurement and the waist measurement and balancing the suppression against them, including the ease. However, this measurement allows us to understand the curvature recurring between the backup point of the waist and the scapula. This then allow us some mechanism to consider how to distribute shaping around, how much and how strong an adult we need in the back.

Measurement $D$ shows the shaping of the waist relative to the shoulder which indicates how side pressure there would be. This may be important when using a Bunka [12]draft or other drafts that have two darts at the front. Similarly, ESMOD[13] is a method where a dart fits to the bust and another dart sits between the side seam and the bust point. This shapes the side of the body.

This is clearly a mechanism for understanding the curvature of the body, coming out of the waist into the shoulder region and may help understand how much darting is required. To effectively balance the suppression by responding to the body, more bodily cues are required.

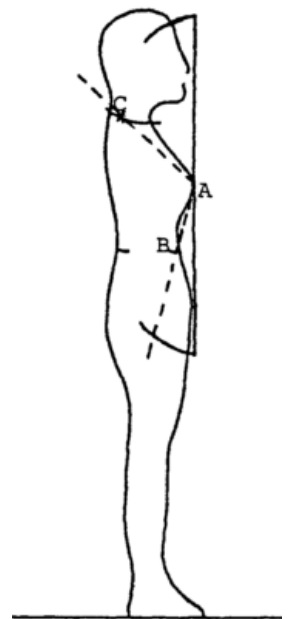

A

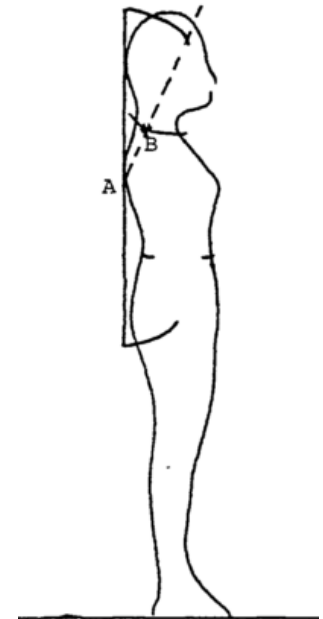

B

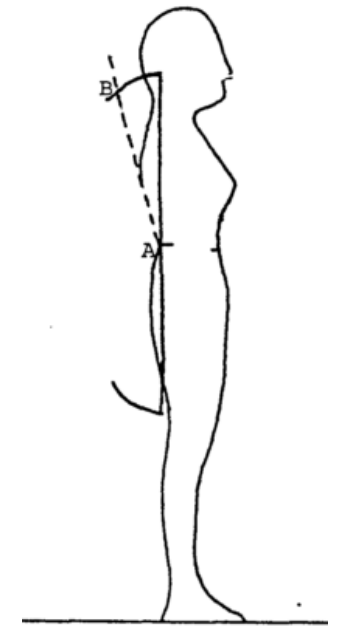

C

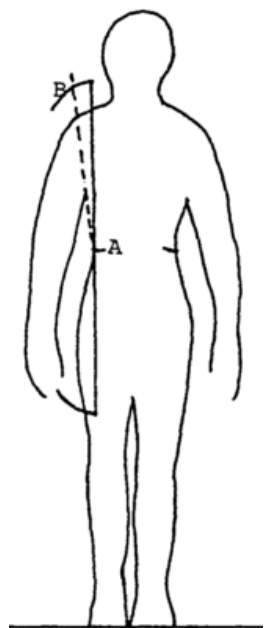

D

Figure 10

Source:[25, pp. 38-44] 


\section{Conclusions}

The main contribution this study has made is that it has made clear areas where measurements are required for pattern construction. These are defined as outputs within body scanner systems. This would allow the body scanner to offer more suitable measurement support for pattern drafting methods, a need which is recognised in other studies [22]

This research addresses the issue of landmarking in terms of points that define the placement of measurements. Manual methods and body scanning differ, with the first employing the body's geography (frequently using reference to important areas of the skeleton) and the second relies on the geometrical shape of the surface as its reference to create landmarks and take measurements. Whilst the scanner cannot automatically take all measurements, some can be collected by the manual software tools, with guidance from the automated landmarks to help in their placement.

Progress regarding the definition of landmarking may permit the mitigation of some potential inaccuracy. In which case, the definitions for landmarks and measurements will become similar for both manual and scanner methods.

\section{References}

[1] E. C. McKinney, E. Bye, and K. LaBat, "Building patternmaking theory: a case study of published patternmaking practices for pants," Int. J. Fash. Des. Technol. Educ., vol. 5, no. March 2015, pp. 153-167, 2012.

[2] E. C. Hlaing, S. Krzywinski, and H. Roedel, "Garment prototyping based on scalable virtual female bodies," Int. J. Cloth. Sci. Technol., vol. 25, no. 3, pp. 184-197, 2013.

[3] C. Fujii, M. Takatera, and K. O. Kim, "Effects of Combinations of Patternmaking Methods and Dress Forms on Garment Appearance," Autex Res. J., vol. 0, no. 0, pp. 1-10, 2016.

[4] H. W. Lim and T. Cassidy, "A Comparative Study of Trouser Pattern Making Methods," J. Text. Eng. Fash. Technol., vol. 1, no. 5, pp. 1-9, 2017.

[5] E. McKinney, S. Gill, A. Dorie, and S. Roth, "Body-to-Pattern Relationships in Womens Trouser Drafting Methods: Implications for Apparel Mass Customization," Cloth. Text. Res. J., vol. 35, no. 1, pp. 1-17, 2017.

[6] J. Anderson, The Tailors Complete Instructor in Cutting. Edinburgh: David. C. Simpson, 1876.

[7] J. P. Thornton, Thorntons Anatomy and Geometry in Garment Cutting. London, UK: J. P. THORNTON.

[8] E. Bye, K. L. LaBat, and M. R. Delong, "Analysis of Body Measurement Systems for Apparel," Cloth. Text. Res. J., vol. 24, no. 2, pp. 66-79, 2006.

[9] W. Aldrich, Metric Pattern Cutting for Women's Wear, 6th ed. NJ, USA: Wiley, 2015.

[10] H. J. Armstrong, Patternmaking for Fashion Design, 5th ed. Edinburgh: Pearson Education Limted, 2014.

[11] A. Beazley and T. Bond, Computer-aided Pattern Design and Product Development. Oxford: Blackwell Science, 2003.

[12] Bunka, Fundamentals of garment design. Tokyo: Bunka Publishing Bureau, 2009.

[13] ESMOD, Women's garment 2- Become a pattern drafter. Esmod éd, 2009.

[14] G. Holman, Pattern Cutting Made Easy: AStep by Step introduction. London: Batsford, 1997.

[15] F. Khalil, Fathi Khalil's Encyclopedia of Clothing Construction Techniques. fathi khalil, 1985.

[16] P. Kunick, Sizing, pattern construction and grading for women's and children's garments: a treatise and standard textbook for all who are engaged in the production and distribution of women's and children's garments by Kunick, Philip. Published London: Philip Kunick Ltd, 1967.

[17] E. Thatha, Tasmim Almukhttatat Walkhyatah, 1st ed. Amman: Dar Elmoustakbal, 1995.

[18] M. Shoben and J. Ward, Pattern cutting and making up. Vol.2. The simple approach to modern tailoring. Published London: LCFS Fashion Media, 2000. 
[19] A. Beazley, "Size and fit: Procedures in undertaking a survey of body measurements - Part 1," J. Fash. Mark. Manag., vol. 2, no. 1, pp. 55-85, 1997.

[20] ISO, "7250-1:2010: Basic human body measurements for technological design - Part 1: Body measurement definitions and landmarks." International Standards Organisation, Brussels, 2010.

[21] ISO, "BS ISO 8559-1:2017 - Size designation of clothes - Part 1: Anthropometric definitions for body measurement," Iso 8559-1:2017. British Standards Institution, p. 80, 2017.

[22] S. GILL, M. AHMED, C. J. PARKER, and S. G. HAYES, "Not All Body Scanning Measurements Are Valid: Perspectives from Pattern Practice," in Proceedings of 3DBODY.TECH 2017 - 8th International Conference and Exhibition on3D Body Scanning and Processing Technologies, Montreal QC, Canada, 11-12 Oct. 2017, 2017, pp. 43-52.

[23] S. Gill, "A review of research and innovation in garment sizing, prototyping and fitting," Text. Prog., vol. 47, no. January, pp. 1-85, 2015.

[24] S. Gill and N. Chadwick, "Determination of ease allowances included in pattern construction methods," Int. J. Fash. Des. Technol. Educ., vol. 2, no. 1, pp. 23-31, 2009.

[25] L. J. Lesko, "Bodice fit compared: conventional alterations with and without graphic somatometry," lowa State University, 1982.

[26] L. Shen and J. Huck, "Bodice Pattern Development Using Somatographic and Physical Data," Int. J. Cloth. Sci. Technol., vol. 5, pp. 6-16, 1993. 